\title{
Analisis Pengelolaan Keuangan Desa Pada Desa Passi dan Desa Muntoi Timur Kecamatan Passi Barat Kabupaten Bolaang Mongondow
}

\section{MAGDALENA MAKALALAG ${ }^{1}$, JENNY MORASA $^{2}$, HENDRIK MANOSSOH $^{3}$}

Program Studi Magister Akuntansi Fakultas Ekonomi dan Bisnis Universitas Sam Ratulangi Email: lenamakalalag2804@gmail.com ${ }^{1}$, jennymorasa@unsrat.ac.id ${ }^{2}$, hendrik_manossoh@yahoo.com ${ }^{3}$

\begin{abstract}
This study aims to analyze village financial management, constraints that hamper financial management and efforts to overcome those obstacles in Passi Village and Muntoi Timur Village Passi Barat District Bolaang Mongondow Regency. This is a qualitative research. Content analysis is used to analyze data consisting of data reduction, data display and conclusion drawing. The results showed that the village financial management in Passi Village and Muntoi Timur Village Passi Barat District Bolaang Mongondow Regency was partly in accordance with Minister of Home Affairs Regulation No. 113 of 2014 concerning Village Financial Management. But there are still some obstacles, namely bureaucratic structure, human resources, and communication. Efforts must be made in relation to the bureaucratic structure, namely the replacement of the Village Head and conducting audits. Efforts in relation to human resources must be carried out to increase the capacity of the Village Officials and to replace the Village Officials in accordance with the Village Law Number 6 of 2014. Efforts related to the communication of the Village Government have collaborated with BPD through the intermediary of the District Government.
\end{abstract}

Keywords: Village Financial Management, Regulations, Constraints and Efforts

\begin{abstract}
Abstrak. Penelitian ini bertujuan menganalisis pengelolaan keuangan desa, kendala yang menghambat serta upaya untuk mengatasi kendala atas pengelolaan keuangan desa pada Desa Passi dan Desa Muntoi Timur Kecamatan Passi Barat Kabupaten Bolaang Mongondow. Metode penelitian ini adalah penelitian kualitatif eksploratori. Content analysis (analisis isi) digunakan untuk menganalisis data yang terdiri dari reduksi data, tampilan data dan penarikan kesimpulan. Hasil penelitian menunjukkan bahwa pengelolaan keuangan desa pada Desa Passi dan Desa Muntoi Timur Kecamatan Passi Barat Kabupaten Bolaang Mongondow sebagian sudah sesuai dengan Peraturan Menteri Dalam Negeri Nomor 113 Tahun 2014 tentang Pengelolaan Keuangan Desa. Namun masih ditemukan beberapa kendala yaitu struktur birokrasi, sumber daya manusia, dan komunikasi. Upaya-upaya yang harus dilakukan terkait struktur birokrasi yaitu penggantian Kepala Desa dan melakukan audit. Upaya terkait sumberdaya manusia dilakukan kegiatan peningkatan kapasitas Aparat Desa dan melakukan penggantian Aparat Desa sesuai dengan Undang-Undang Desa Nomor 6 Tahun 2014. Upaya terkait komunikasi Pemerintah Desa telah bekerjasama dengan BPD melalui perantara Pemerintah Kecamatan.
\end{abstract}

Kata Kunci: Pengelolaan Keuangan Desa, Regulasi, Kendala dan Upaya.

\section{Pendahuluan}

Nawacita adalah sembilan agenda prioritas dalam kabinet kerja Presiden Joko Widodo dan Wakil Presiden Jusuf Kalla. Salah satu agenda prioritas ketiga Nawacita adalah membangun Indonesia dari pinggiran dengan memperkuat daerah-daerah dan desa-desa dalam kerangka Negara Kesatuan Republik Indonesia. Nawacita ketiga ini terbukti dengan adanya realisasi dana untuk pembangunan desa melalui Dana Desa yang diatur dalam Undang-Undang Nomor 6 Tahun 2014 tentang Desa.

Dengan disahkannya Undang-Undang No. 6 tahun 2014 tentang Desa pada tanggal 15 Januari 2014, Desa-Desa di Indonesia akan mengalami reposisi dan pendekatan baru dalam pelaksanaan pembangunan dan tata kelola pemerintahannya. Undang-Undang Desa memberi jaminan yang lebih pasti bahwa setiap desa akan menerima dana dari pemerintah melalui anggaran negara dan daerah yang jumlahnya berlipat, jauh di atas jumlah yang selama ini tersedia dalam anggaran desa. Kebijakan ini memiliki konsekuensi terhadap proses pengelolaannya yang seharusnya dilaksanakan secara 
profesional, efektif dan efisien, serta akuntabel yang didasarkan pada prinsip-prinsip manejemen publik yang baik agar terhindarkan dari resiko terjadinya penyimpangan, penyelewengan dan korupsi.

Diterbitkannya Peraturan Menteri Dalam Negeri Nomor 113 Tahun 2014 tentang pengelolaan keuangan Desa memberikan landasan bagi semakin otonomnya desa secara praktik, bukan hanya sekedar normatif. Dalam Ketentuan Umum Permendagri Nomor 113 Tahun 2014 disebutkan bahwa pengelolaan keuangan desa adalah keseluruhan kegiatan yang meliputi perencanaan, pelaksanaan, penatausahaan, pelaporan, dan pertanggungjawaban keuangan desa. Sehingga dengan hak otonom tersebut harapannya desa dapat mengelola keuangannya secara mandiri. Baik mengelola pendapatan dan sumber-sumber pendapatan juga mengelola pembelanjaan anggaran.

Akan tetapi, pada kenyataannya sangat banyak desa yang belum dapat memanfaatkan keistimewaannya tersebut. Penyusunan dan pelaksanaan Anggaran Pendapatan dan Belanja Desa (APBDes) seharusnya diisi dengan kegiatan/program-program yang dibutuhkan oleh masyarakat, misalnyal kegiatan pembangunan fisik. Akan tetapi kadangkala pelaksanaan dari kegiatan pembangunan fisik tersebut tidak dilaksanakan sesuai dengan yang tercantum dalam APBDes (volume kurang, kualitas kurang dan lain-lain), bahkan ada yang sama sekali tidak/belum dilaksanakan.

Pengelolaan keuangan desa pada Kabupaten Bolaang Mongondow diatur dalam Peraturan Bupati Nomor 10 Tahun 2017 tentang Pedoman Pengelolaan Keuangan Desa. Berdasarkan data yang diperoleh penulis melalui Pendamping Ekonomi Desa (PED) Kabupaten Bolaang Mongondow menunjukkan progres penyaluran Dana Desa yang terjadi sejak Tahun 2015 sampai dengan Tahun 2017 bahwa terjadi peningkatan jumlah penyaluran Dana Desa yang cukup signifikan dan dibarengi dengan penggunaan Dana Desa tersebut yang juga meningkat. Kondisi ini menggambarkan keadaan dimana Desa-Desa di daerah ini membutuhkan konsep pengelolaan keuangan yang lebih baik lagi, guna efektif dan efisiennya penggunaan dana Desa yang disalurkan pemerintah. Hal ini juga pasti akan mempengaruhi kegiatan pemerintahan desa dalam mengelola keuangan desa yang tercermin dari kepemerintahan yang bersih (good governance) dalam desa.

Penulis memfokuskan penelitian ini pada 2 desa di Kecamatan Passi Barat Kabupaten Bolaang Mongondow. Kecamatan Passi Barat memiliki 13 Desa yaitu Muntoi, Poyuyanan, Lobong, Passi, Bintau, Bulud, Otam, Wangga, Inuai, Passi II, Muntoi Timur, Otam Barat, dan Wangga Satu. Berdasarkan data yang diperoleh penulis melalui data Pendamping Ekonomi Desa (PED) Kabupaten Bolaang Mongondow diperoleh uraian laporan kegiatan Progres Penyaluran Dana Desa Kecamatan Passi Barat mulai dari Tahun 2015 sampai dengan Tahun 2017 yaitu Rekap Rekening Kas Desa (Transfer Rekening Kas Umum Daerah/RKUD) dan total penggunaan dana Desa untuk Tahun Anggaran 2015 sampai dengan Maret 2016 adalah sebesar Rp2.795.001.398,-; Rekap Rekening Kas Desa (Transfer Rekening Kas Umum Daerah/RKUD) dan total penggunaan dana Desa untuk Tahun Anggaran 2016 adalah sebesar Rp7.772.547.990,-; sedangkan untuk Rekap Rekening Kas Desa (Transfer Rekening Kas Umum Daerah/RKUD) dan total penggunaan Dana Desa Tahun Anggaran 2017 adalah sebesar Rp9.930.570.000,-. Namun, nilai Dana Desa Pada Tahun 2017 ini belum semua dapat ditransfer dari Rekening Kas Umum Daerah ke Rekening Kas Desa. Hal ini disebabkan masih terdapat 2 (dua) desa yang belum dapat melakukan pencairan Dana Desa karena terdapat permasalahan di dalam desa tersebut. Uraian di atas menunjukkan bahwa terjadi peningkatan jumlah penyaluran Dana Desa yang cukup signifikan dan dibarengi dengan penggunaan Dana Desa yang juga meningkat.

Berdasarkan wawancara penulis dengan Pendamping Desa Bidang Pemberdayaan dan Ekonomi Kecamatan Passi Barat ibu Elva Pobela SP, MSi diperoleh hasil bahwa di Desa Passi dan Desa Muntoi Timur Kecamatan Passi Barat ditemukan beberapa kendala dalam pengelolaan keuangan desa. Kedua Desa ini termasuk dalam kondisi desa yang bermasalah dalam pengelolaan keuangan desa untuk Tahun Anggaran 2016. Pada tahun anggaran ini kedua desa ini terkendala dari sisi penatausahaan, dimana Pelaksana Teknis Pengelolaan Keuangan Desa (PTPKD) untuk kedua desa ini belum mampu membuat laporan pertanggungjawaban realisasi pelaksanaan APBDes tahun anggaran 2016. Hal ini karena pemerintah di 2 (dua) desa ini masih menggunakan bantuan pihak luar dalam membuat laporan pertanggungjawaban. Kondisi ini dipengaruhi oleh kendala sumberdaya manusia yang berperan dalam pengelolaan keuangan desa yang belum dapat diandalkan. Akibatnya, proses pelaporan dan pertanggungjawaban dalam pengelolaan keuangan desa tidak dapat dilakukan sebagaimana mestinya. Kedua desa ini tidak membuat laporan pertanggungjawaban APBDes atas kegiatan yang telah dilakukan 
dan tidak dapat menyajikan laporan pertanggungjawaban ABPDes tersebut kepada Bupati selaku Pemerintah Daerah. Kondisi ini memicu sikap pihak Pemerintah Daerah melalui Camat Kecamatan Passi Barat untuk menindaklanjuti hal tersebut dengan memberikan sanksi, dimana kedua desa ini tidak dapat melakukan pencairan Dana Desa untuk periode anggaran Tahun 2017.

Selain itu, pada penetapan APBDes Tahun Anggaran 2017 di Desa Passi dan Desa Muntoi Timur juga menemui kendala, dimana Badan Permusyawaratan Desa (BPD) tidak melakukan persetujuan penandatanganan APBDes untuk Tahun Anggaran 2017, sehingga APBDes pada tahun anggaran tersebut tidak dapat disetujui oleh Bupati untuk tindaklanjut pelaksanaannya. Adapun kendala yang ditemukan pada penetapan APBDes Tahun Anggaran 2017 yaitu pada kegiatan perencanaan BPD menemukan kondisi dimana Kepala Desa Muntoi Timur membuat skenario sendiri dengan menentukan sendiri pihak-pihak yang berperan dalam kegiatan Musyawarah Perencanaan dan Pembangunan Desa (Musrenbangdes) dengan tujuan untuk memperoleh dukungan atas usulan yang diajukan oleh Kepala Desa tersebut. Kasus lain yaitu pada Desa Passi, dimana kegiatan Musrenbangdes Tahun Anggaran 2017 tetap dilakukan sesuai aturan namun hasil dari Musrenbangdes dirubah sepihak oleh Kepala Desa ketika tidak dikawal ketat oleh pihak-pihak seperti Badan Permusyawaratan Desa (BPD) dan Pendamping Desa. Kondisi yang terjadi pada kedua desa ini menimbulkan kendala struktur birokrasi yang tidak tertata dengan baik sehingga menimbulkan konflik antara Pemerintah Desa dengan BPD. Konflik yang terjadi ini juga mengakibatkan komunikasi di antara kedua belah pihak dalam Pemerintahan Desa yaitu Kepala Desa dengan BPD tidak berjalan sebagaimana mestinya. Sehingga menimbulkan kendala komunikasi yang tidak baik.

Pada kegiatan pelaksanaan, akibat keterlambatan pencairan Dana Desa Tahun Anggaran 2017 hingga pada Bulan September 2017, Desa Passi dan Desa Muntoi Timur mengalami keterlambatan dalam pelaksanaan dan penatausahaan kegiatan pengelolaan keuangan desa. Hal ini mengakibatkan kedua desa ini tidak dapat membuat laporan pertanggungjawaban APBDes untuk Tahun Anggaran 2017 tepat waktu dan tidak dapat menyajikan laporan pertanggungjawaban APBDes tersebut kepada Bupati sesuai dengan peraturan yang berlaku. Berdasarkan uraian kondisi pengelolaan keuangan desa di Desa Passi dan Desa Muntoi Timur Kecamatan Passi Barat, dibutuhkan konsep pengelolaan keuangan desa berdasarkan Peraturan Menteri Dalam Negeri (Permendagri) Nomor 113 Tahun 2014, sehingga kendala-kendala seperti kendala struktur birokrasi, kendala sumberdaya manusia serta kendala komunikasi yang menghambat terciptanya pengelolaan keuangan desa yang baik dapat dicegah dan ditemukan upaya-upaya untuk mengatasi kendala-kendala tersebut.

Tujuan diadakannya penelitian ini untuk: 1) menganalisis pengelolaan keuangan desa dengan regulasi yang ditetapkan pemerintah; 2) menganalisis kendala yang menghambat pengelolaan keuangan desa; 3) menganalisis upaya untuk mengatasi kendala yang menghambat pengelolaan keuangan desa pada Desa Passi dan Desa Muntoi Timur Kecamatan Passi Barat Kabupaten Bolaang Mongondow.

\section{Model Analisis}

Model analisis pada penelitian ini menggunakan content analysis (analisis isi) yaitu membuat transkrip hasil wawancara, mendengarkan dengan seksama, kemudian menuliskan kata-kata yang didengar sesuai dengan apa yang ada di rekaman tersebut. Model analisis penelitian dapat digambarkan dalam kerangka konseptual penelitian seperti pada gambar 3.1 berikut ini: 
Gambar 1.1. Kerangka Konseptual Penelitian

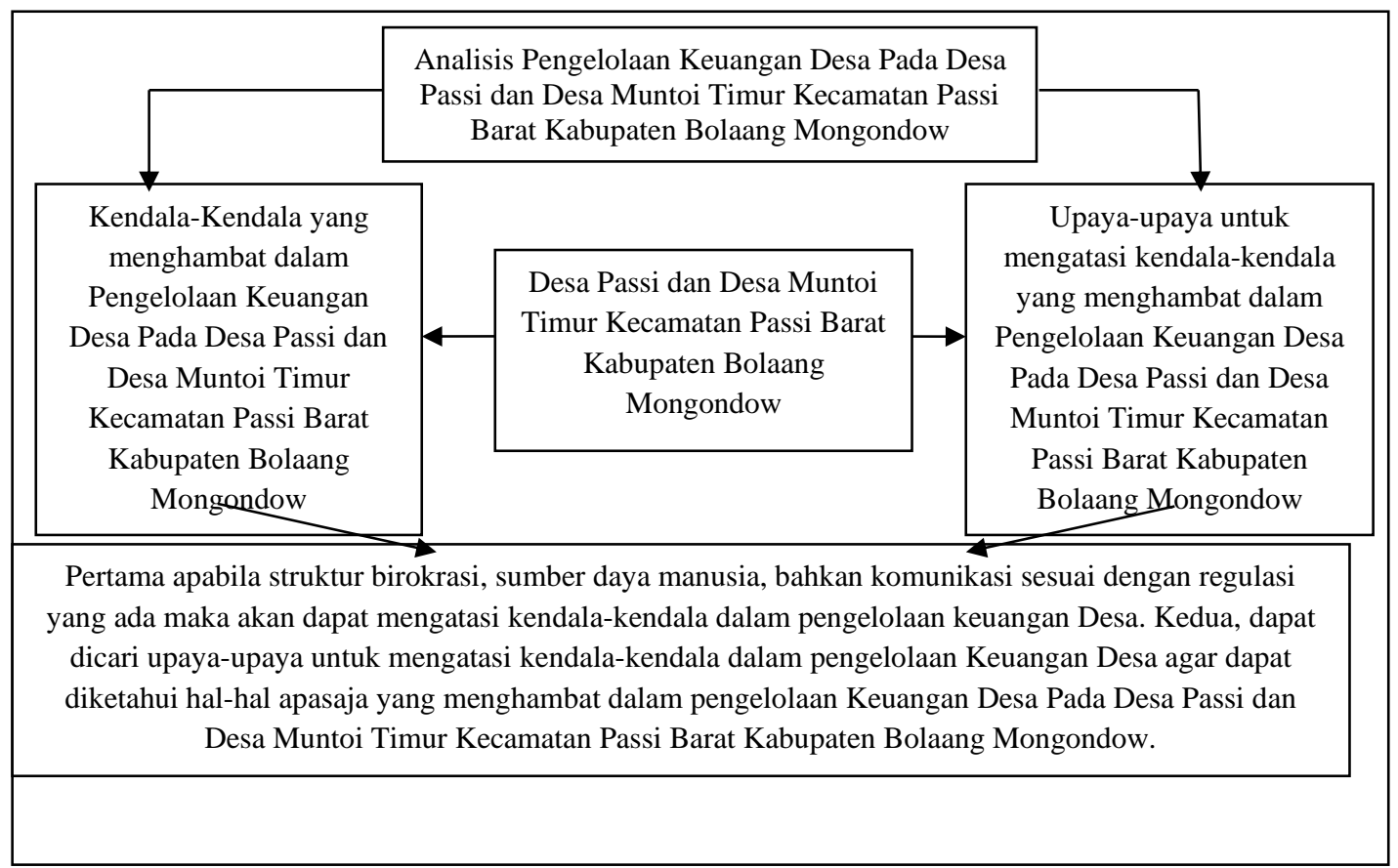

Sumber: (Data olahan, 2018).

\section{Metode Penelitian}

Penelitian ini menggunakan metode penelitian kualitatif dengan pendekatan eksploratori (exploratory approach). Metode kualitatif ini dipilih agar data yang diperoleh akan lebih lengkap, lebih mendalam, kredibel dan bermakna sehingga tujuan penelitian dapat dicapai (Sugiyono, 2017:1).

Teknik pengumpulan data yang digunakan penulis dalam penelitian ini yaitu wawancara mendalam (in-depth interview) dan dokumentasi. Informan dalam penelitian ini terdiri dari Perangkat Desa dan yang terpilih sebanyak 9 informan. Uji kredibilitas yang dilakukan dalam penelitian ini menggunakan triangulasi sumber.

\section{Analisis dan Pembahasan}

Untuk menjawab permasalahan pertama dikemukakan 5 (lima) tema yaitu: perencanaan, pelaksanaan, penatausahaan, pelaporan, dan pertanggungjawaban. Selanjutnya, untuk menjawab masalah kedua ditemukan 3 (tiga) tema yaitu: kendala struktur birokrasi, kendala sumber daya manusia, dan kendala komunikasi. Dan untuk menjawab masalah ketiga ditemukan 3 (tiga) tema yaitu: upaya struktur birokrasi, upaya sumber daya manusia, dan upaya komunikasi.

\section{Analisis Kesesuaian Pengelolaan Keuangan Desa Pada Desa Passi dan Desa Muntoi Timur Kecamatan Passi Barat Kabupaten Bolaang Mongondow dengan Peraturan Menteri Dalam Negeri Nomor 113 Tahun 2014. Perencanaan}

Penyusunan APBDes menjadi prosedur awal dalam perencanaan yaitu menyusun Rancangan Kerja Peraturan Desa (RKPDes) tentang APBDes oleh Sekretaris Desa kemudian disampaikan kepada Kepala Desa dan Badan Permusyawaran Desa (BPD) dan selanjutnya disepakati oleh semua pihak dalam hal ini termasuk masyarakat desa, untuk hasil penelitian ini terdapat kesesuaian untuk proses penyusunan, penetapan, dan pendelegasian evaluasi rancangan APBDes tapi tidak disebutkan batas waktu pendelegasian APBDes tersebut. Hanya pada proses ketidaksesuaian di dalam hasil evaluasi rancangan APBDes dengan undang-undang yang terdapat kesesuaian dengan peraturan yang ada. 
Badrudin (2013:53) menyatakan bahwa perencanaan berasal dari kata rencana yaitu produk perencanaan, sedangkan perencanaan adalah proses penentuan rencana. Banyak perencanaan organisasi yang gagal gara-gara perencanaan yang tidak mempunyai pijakan yang relevan dengan kondisi sosial, ekonomi, politik, maupun budaya masyarakat.

Hasil penelitian ini sejalan dengan penelitian Indrianasari (2017) yang mengemukakan Perangkat Desa cukup berperan dalam pengelolaan keuangan desa dan secara keseluruhan pelaksanaan pengelolaan keuangan desa sesuai dengan Permendagri No. 113 Tahun 2014. Pemerintah Desa mampu memanfaatkan SDM dari Perangkat Desa dalam hal pengelolaan keuangan desa khususnya mengenai perencanaan, penggunaan, penatausahaan, pelaporan dan pertanggungjawaban. Selanjutnya, Subroto (2009) yang membahas bahwa untuk perencanaan dan pelaksanaan kegiatan Alokasi Dana Desa, sudah menampakkan adanya pengelolaan yang akuntabel dan transparan. Hal ini juga sejalan dengan hasil penelitian penulis.

\section{Pelaksanaan}

Dalam kegiatan pelaksanaan ini terdapat pembahasan tentang penerimaan dan pengeluaran kas desa harus tercatat dalam Rekening Desa dan segala kegiatan yang berkaitan dengan penerimaan dan pengeluaran kas ini harus tercatat sesuai dengan bukti yang ada, pelaksanaan dalam pengelolaan keuangan desa juga membahas tentang jumlah tertentu kas pada Bendahara dalam memenuhi kebutuhan operasional desa, proses pendanaan/pembiayaan, PTPKD akan memverifikasi proposal dari TPK dilanjutkan dengan pengajuan Surat Perintah Pembayaran (SPP) yang disetujui oleh Kepala Desa dan dibayarkan oleh Bendahara Desa, hasil analisis ditemukan kesesuaian dengan peraturan yang ada. Hanya pada proses menyangkut perubahan APBDes yang terdapat kesesuaian yaitu pada poin peristiwa khusus, akan tetapi pada poin lain tidak disebutkan.

Faktor sikap pelaksana menurut Edward III dalam Tahir (2014) merupakan faktor penting ketiga dalam pendekatan mengenai studi implementasi kebijakan publik. Jika implementasi kebijakan diharapkan berlangsung efektif, para pelaksana kebijakan tidak hanya harus mengetahui apa yang harus dilakukan dan memiliki kapabilitas untuk melaksanakannya tetapi mereka juga harus mempunyai keinginan untuk melaksanakan kebijakan tersebut.

Hasil penelitian ini sejalan dengan penelitian Astuty (2013) dimana secara umum akuntabilitas sudah berjalan dengan baik, walaupun masih ada beberapa kelemahan yang harus dibenahi pada tahap pelaksanaan yang hanya berjalan selama enam bulan dan selanjutnya program ini tidak berjalan. Namun demikian, sisa dana yang tidak berjalan tersebut dialihkan untuk kegiatan lain. Selanjutnya, Abidin (2015) menyebutkan pelaksanaan keuangan desa menunjukkan perbaikan dari sisi tertib pelaksanaan administrasi keuangan, kualitas laporan keuangan, dan penyerapan anggaran pada kegiatan yang telah diprogramkan. Selanjutnya, Taufik (2009) dimana ruang lingkup pengelolaan keuangan desa meliputi kekayaan desa yang dikelola langsung oleh Pemerintah Desa, yaitu APBDes serta pengelolaan keuangan desa dilaksanakan dalam suatu sistem yang terintegrasi yang diwujudkan dalam APBDes yang setiap tahun ditetapkan dengan peraturan desa.

\section{Penatausahaan}

Proses penatausahaan yang dilakukan Bendahara ini mulai dari pencatatan penerimaan dan pengeluaran kas desa terkait kegiatan yang dilakukan berdasarkan APBDes serta mempertanggungawabkan kas tersebut dengan membuat laporan pertanggungjawaban setiap tahap kegiatan kepada Kepala Desa, terdapat kesesuaian pada proses penatausahaan secara umum, tapi untuk kegiatan setiap bulan tidak disebutkan batas waktu pertanggungjawabannya tersebut. Selanjutnya, kegiatan penatausahaan dalam pengelolaan keuangan desa juga harus menggunakan pencatatan pada beberapa jenis buku dalam laporan pencatatan yaitu buku kas umum dan buku pembantu pajak, terdapat kesesuaian pada 2 jenis buku laporan pertanggungjawaban Bendahara Desa, tapi tidak menyebutkan Buku Bank.

Penatausahaan menurut Peraturan Menteri Dalam Negeri Nomor 113 Tahun 2014 menyebutkan

1) penatausahaan dilakukan oleh Bendahara Desa. 2) Bendahara Desa wajib melakukan pencatatan setiap penerimaan dan pengeluaran serta melakukan tutup buku setiap akhir bulan secara tertib. 3) Bendahara Desa wajib mempertanggungjawabkan uang melalui laporan pertanggungjawaban. 4) 
laporan pertanggungjawaban disampaikan setiap bulan kepada Kepala Desa dan paling lambat tanggal 10 bulan berikutnya. 5) penatausahaan penerimaan dan pengeluaran, menggunakan Buku Kas Umum, Buku Kas Pembantu Pajak; dan Buku Bank.

Hasil penelitian ini sejalan dengan penelitian Mamelo (2016) menyebutkan pelaksanaan dan penatausahaan Dana Desa telah disusun sesuai dengan peraturan. Aplikasi komputer SIMDA telah digunakan untuk mengelola Dana Desa, meskipun belum telah digunakan secara optimal. Pengawasan untuk staf manajemen diperlukan untuk meningkatkan administrasi.

\section{Pelaporan}

Kegiatan pelaporan yang dilakukan oleh Pemerintah Desa untuk pelaporan APBDes Tahun 2017 yang dilakukan dalam 2 tahap, sehingga laporan yang disampaikan oleh Kepala Desa dibuat 2 tahap yaitu tahap 1 dan tahap 2. Selanjutnya, Laporan pertanggungjawaban dibuat oleh Pemerintah Desa dalam hal ini PTPKD dan dilaporkan oleh Kepala Desa kepada Bupati terkait kegiatan pengelolaan keuangan desa periode tertentu, hal ini terdapat kesesuaian hanya pada proses penyampaian laporan, tapi tidak disebutkan jenis laporan apa yang akan dilaporkan oleh Kepala Desa kepada Bupati. Selain itu, waktu pelaporan juga tidak disebutkan.

Pelaporan menurut Peraturan Menteri Dalam Negeri Nomor 113 Tahun 2014 menyebutkan bahwa 1) Kepala Desa menyampaikan Laporan Realisasi Pelaksanaan APBDesa kepada Bupati/Walikota berupa laporan semester pertama dan laporan semester akhir tahun. 2) laporan semester pertama berupa laporan realisasi APBDesa. 3) laporan realisasi pelaksanaan disampaikan paling lambat pada akhir Bulan Juli tahun berjalan. 4) laporan semester akhir tahun disampaikan paling lambat pada akhir Bulan Januari tahun berikutnya.

Hasil penelitian ini sejalan dengan penelitian Agustin et al (2017) menyampaikan laporan realisasi APBNagari semester I dan II hanya dapat dipenuhi walaupun hanya dipenuhi oleh 71,43\% nagari. Selain itu, walaupun dalam menyampaikan laporan realisasi APBNagari semester I dan laporan pertanggungjawaban pelaksanaan APBNagari hanya dapat dipenuhi oleh 50\% nagari, namun semua nagari di kabupaten Pasaman Barat telah mampu menyampaikan laporan realisasi APBN nagari semester kedua tepat waktu.

\section{Pertanggungjawaban}

Pada proses pertanggungjawaban, Pemerintah Desa dalam hal ini PTPKD membuat laporan pertanggungjawaban dan Kepala Desa melaporkan Laporan Pertanggungjawaban atas kegiatan pengelolaan keuangan desa kepada Bupati selaku Pemerintah Daerah pada akhir tahun, terdapat kesesuaian hanya pada proses pertanggungjawabannya, tapi tidak menyebutkan bentuk laporan serta rincian pertanggungjawaban yang akan dilaporkan. Proses selanjutnya, Pemerintah Desa perlu menyiapkan dokumen-dokumen pendukung dalam laporan pertanggungjawaban kegiatan antara lain Buku Pembantu Kas Kegiatan, RAB, Surat Permintaan Pembayaran, Realisasi Pelaksanaan Kegiatan serta dokumentasi kegiatan, sudah ditemukan kesesuaian pada dokumen pendukung, tapi belum sesuai pada laporan pertanggungjawabannya.

Jensen dan Meckling (1976:5) mengatakan bahwa hubungan keagenan sebagai kontrak antara satu orang atau lebih, dimana pihak-pihak yang bertindak adalah sebagai pemegang saham (pemilik) yang menunjuk orang lain sebagai agen dengan kata lain manajer untuk membantu melakukan jasa untuk kepentingan pemilik termasuk mendelegasikan kekuasaan dalam pengambilan keputusan. Manajer sebagai pengelola (dalam hal ini agen) perusahaan lebih banyak mengetahui informasi internal dan perkembangan perusahaan dimasa yang akan datang dibandingkan dengan pemilik, karena manajer langsung melakukan tindakan manajemen dalam perusahaan sedangkan pemilik terkadang tidak secara langsung mengelola perusahaan. Pemerintah Desa selaku pelaksana kegiatan pengelolaan keuangan desa tentu harus menunjukkan bahwa kinerja mereka sesuai dengan aturan yang ada, sehingga informasi keuangan yang dihasilkan yang dapat di pertanggungjawabkan kepada masyarakat serta pihak-pihak yang berkepentingan di dalamnya.

Hasil penelitian ini sejalan dengan penelitian Lestari et al (2014) yang mengemukakan bahwa akuntabilitas pengelolaan keuangan berlangsung secara konsisten setiap bulan dengan menggunakan sistem akuntansi sederhana (sistem tiga kolom, yaitu debet, kredit dan saldo). Selanjutnya, Sulumin 
(2015) mengemukakan di Kabupaten Donggala sudah terwujud hukum beroperasi, yang institusinya berhasil memahami pengaturan keuangan negara secara bertanggungjawab. Pengawasan di dalam untuk menggunakan Alokasi Dana Desa mulai kabupaten hingga ke desa dilakukan secara efisien merujuk pada peraturan yang berlaku.

\section{Kendala-Kendala Dalam Pengelolaan Keuangan Desa Pada Desa Passi dan Desa Muntoi Timur Kecamatan Passi Barat Kabupaten Bolaang Mongondow \\ Kendala Struktur Birokrasi}

Adanya intervensi dari salah satu pihak dalam struktur organisasi Pemerintahan Desa, dalam hal ini dari BPD terhadap Kepala Desa menghambat jalannya pelaksanaan kegiatan. Kondisi lain tentang kendala dalam struktur birokrasi ini yaitu tidak adanya koordinasi yang baik antara Kepala Desa dengan BPD, dimana BPD menganggap bahwa Kepala Desa tidak mematuhi prosedur pengelolan keuangan desa sesuai dengan peraturan yang ada.

Tyler dalam Septiani (2005) meyebutkan bahwa terdapat dua perspektif dasar dalam literatur sosiologi mengenai kepatuhan pada hukum, yang disebut instrumental dan normatif. Pengelolaan keuangan desa tentu harus sesuai dengan aturan yang ada, karena pada akhirnya akan menghasilkan informasi yang dapat di pertanggungjawabkan kepada masyarakat serta pihak-pihak yang berkepentingan.

Hasil penelitian ini sejalan dengan penelitian Subroto (2009) yang membahas dari sisi administrasi masih diperlukan adanya pembinaan lebih lanjut. Kendala utamanya adalah belum efektifnya pembinaan Aparat Pemerintahan Desa. Selanjutnya, penelitian Salindeho (2017) yang menemukan hambatan dalam pengelolaan dan pemanfaatan Dana Desa, misalnya regulasi yang menyebabkan hambatan dalam struktur birokrasi.

\section{Kendala Sumber Daya Manusia}

Kendala sumber daya manusia terhambat pada saat pelaporan hasil kegiatan karena masih kurangnya sumberdaya manusia yang mampu menyusun laporan hasil kegiatan. Selain itu juga, perekrutan Aparat Desa itu tidak ada syarat-syarat tertentu dan hanya melihat status sosial aparat, hal ini juga semakin menghambat sumberdaya manusia di 2 (dua) desa ini.

Edward III dalam Tahir (2014) menjelaskan bahwa sumber daya manusia penting meliputi Staf dalam ukuran yang tepat dengan keahlian yang diperlukan, informasi serta hal-hal lainnya yang terlibat di dalam implementasinya.

Hasil penelitian ini sejalan dengan penelitian Subroto (2009) dimana dari sisi administrasi masih diperlukan adanya pembinaan lebih lanjut. Kendala utamanya kompetensi sumber daya manusia, sehingga masih memerlukan pendampingan dari aparat Pemerintah Daerah secara berkelanjutan. Selanjutnya, penelitian Abidin (2015) membahas kendala dalam pelaksanaan keuangan desa disebabkan, antara lain, kurangnya keberadaan dan kapasitas sumberdaya perangkat desa serta kemandirian keuangan. Apabila kendala tersebut dapat diatasi, maka pelaksanaan keuangan desa semakin memperkuat terwujudnya tujuan kebijakan Dana Desa dalam Undang-Undang Desa. Selanjutnya, kendala sumberdaya manusia ini juga dikemukakan oleh Mamelo (2016) dimana ada masalah dalam kemampuan sumber daya manusia.

\section{Kendala Komunikasi}

Terdapat hubungan yang renggang antara Pemerintah Desa dengan Badan Pengawas Desa (BPD) dimana terdapat diskomunikasi terkait kegiatan pengelolaan keuangan desa yang dilakukan oleh Pemerintah Desa.

Silalahi (2015:274-275) menyatakan komunikasi penting karena fungsinya dalam organisasi. Pegawai menerapkan tujuan-tujuan spesifik, bekerja untuk memenuhi tujuan tersebut dan menerima hasil tentang progress terhadap tujuan-tujuan itu karena dapat berfungsi sebagai 1) fungsi kontrol. 2) fungsi motivasi. 3) fungsi ekspresi emosi. 4) fungsi informasi. 5) fungsi komando. 6) fungsi integratif.

Hasil penelitian ini sejalan dengan penelitian Furqani (2010) membahas hampir semua proses tidak memenuhi prinsip tanggung jawab karena ada beberapa hal dalam proses yang tidak sesuai dengan Permendagri No. 113. Akuntabilitas sangat rendah karena karena dalam proses tanggung jawab tidak 
melibatkan masyarakat dan BPD yang merupakan salah satu unsur penyebab tidak adanya komunikasi yang baik antara Aparat Pemerintah Desa dengan unsur lain dalam desa.

\section{Upaya Mengatasi Kendala-Kendala Pengelolaan Keuangan Desa Pada Desa Passi dan Desa Muntoi Timur Kecamatan Passi Barat Kabupaten Bolaang Mongondow Upaya Mengatasi Kendala Struktur Birokrasi}

Camat Kecamatan Passi Barat merencanakan untuk Desa Muntoi Timur akan dilakukan penggantian Kepala Desa sesuai dengan permintaan masyarakat dan BPD serta segera melakukan penandatangan rancangan APBDes untuk kegiatan di tahun berikutnya. Sedangkan di Desa Passi, BPD saat ini melakukan penyampaian secara lisan ditujukan ke Bupati untuk meminta BPK melakukan audit atas kegiatan yang dilakukan pada Tahun Anggaran 2016.

\section{Upaya Mengatasi Kendala Sumber Daya Manusia}

Pemerintah Desa sendiri diwajibkan menganggarkan dalam ADD sejumlah biaya untuk pengadaan pelatihan peningkatan kapasitas Aparat Desa. Upaya lain diadakan penggantian Aparat Desa yang memang sudah tidak efektif, terutama hal ini didasarkan pada Undang-Undang Desa Nomor 6 Tahun 2014.

\section{Upaya Mengatasi Kendala Komunikasi}

Pemerintah Desa Passi menerima saran dari Bapak Camat untuk bekerjasama dengan BPD. Kondisi lain, Pemerintah Desa Muntoi Timur sudah mengikuti permintaan BPD untuk mengganti Kepala Desa. Dengan harapan bahwa BPD dapat bekerja sama dengan baik dalam pengelolaan keuangan desa.

\section{Kesimpulan}

Pengelolaan keuangan desa pada Kecamatan Passi Barat Kabupaten Bolaang Mongondow berdasarkan Peraturan Menteri Dalam Negeri Nomor 113 Tahun 2014 tentang Pengelolaan Keuangan Desa disimpulkan bahwa proses perencanaan, pelaksanaan, penatausahaan, pelaporan, dan pertanggungjawaban sebagian terdapat kesesuaian dengan peraturan yang ada. Beberapa ketidaksesuaian menimbulkan kendala-kendala dalam pengelolaan keuangan desa yaitu struktur birokrasi, sumber daya manusia, dan komunikasi. Sehingga, berdasarkan kendala-kendala tersebut dapat dikemukakan upaya-upaya yaitu 1) upaya struktur birokrasi dilakukan penggantian Kepala Desa dan melakukan audit oleh BPK atas permintaan BPK. 2) upaya sumberdaya manusia, desa melakukan pelatihan peningkatan kapasitas Aparat Desa dan mengganti Aparat Desa didasarkan pada UndangUndang Desa Nomor 6 Tahun 2014. 3) upaya komunikasi Pemerintah Desa Passi menerima saran dari Bapak Camat untuk bekerjasama dengan BPD dan Pemerintah Desa Muntoi Timur mengikuti permintaan BPD untuk mengganti Kepala Desa.

\section{Saran}

Perencanaan, pelaksanaan, penatausahaan, pelaporan, dan pertanggungjawaban perlu dipahami setiap proses kegiatan yang ada untuk memperoleh kesesuaian dengan Permendagri Nomor 113 Tahun 2014. Perlu ada pengawasan ketat dalam hal ini oleh Pemerintah Daerah lebih pro aktif untuk menjadi penengah atas permasalahan yang ada. Perlu dilakukan pelatihan khusus seperti peningkatan kapasitas Aparatur Desa, khususnya PTPKD.

\section{Daftar Pustaka}

Abidin, M. Z. (2015). Tinjauan Atas Pelaksanaan Keuangan Desa Dalam Mendukung Kebijakan Dana Desa. Jurnal Ekonomi dan Kebijakan Publik, 6(1), 61-76.

Agustin, H., Arza, F. I., Mulyani, E., \& Fitra, H. (2017). Potret Pertanggung Jawaban Dan Pelaporan Dan Keuangan Nagari Di Kabupaten Pasaman Barat. Wahana Riset Akuntansi, 5(2). 
Astuty, E. (2013). Akuntabilitas Pemerintah Desa Dalam Pengelolaan Anggaran Pendapatan Dan Belanja Desa (APBDes) (Studi pada Alokasi Dana Desa Tahun Anggaran 2011 Di Desa Sareng Kecamatan Geger Kabupaten Madiun). Publika, 1(2).

Badrudin, B. (2013). Dasar-Dasar Manajemen. Bandung: CV Alfabeta

Furqani, A. (2009). Pengelolaan Keuangan Desa Dalam Mewujudkan Good Governance (Studi Pada Pemerintahan Desa Kalimo'ok Kecamatan Kalianget Kabupaten Sumenep) (Doctoral dissertation, Tesis. Program S2 Universitas Pembangunan Nasional" Veteran", Surabaya).

Indrianasari, N. T. (2017). Peran Perangkat Desa Dalam Akuntanbilitas Pengelolaan Keuangan Desa. Assets: Jurnal Ilmiah Ilmu Akuntansi, Keuangan dan Pajak, 1(2), 29-46.

Jensen, M. C, \& W. H Meckling. 1976. Theory of The Firm: Managerial Behaviour, Agency Costs, And Ownership Structure. Journal of Finance Economics, 3(4).

Lestari, A. K. D., Atmadja, A. T., SE, A., Adiputra, I. M. P., SE, S., \& Si, M. (2014). Membedah Akuntabilitas Praktik Pengelolaan Keuangan Desa Pakraman Kubutambahan, Kecamatan Kubutambahan, Kabupaten Buleleng, Provinsi Bali (Sebuah Studi Interpretif Pada Organisasi Publik Non Pemerintahan). JIMAT (Jurnal Ilmiah Mahasiswa Akuntansi) Undiksha, 2(1).

Mamelo, G. Y. R., Kalangi, L., \& Lambey, L. (2016). Analisis Pelaksanaan Dan Penatausahaan Dana Desa Pada Desa-Desa Dalam Wilayah Kecamatan Kotamobagu Timur, Kota Kotamobagu. Jurnal Riset Akuntansi dan Auditing Goodwil, 7(2).

Peraturan Menteri Dalam Negeri Nomor 113 Tahun 2014 Tentang Pedoman Pengelolaan Keuangan Desa.

Salindeho, M. M., Kalangi, L., \& Warongan, J. (2017). Analisis Pengelolaan Dan Pemanfaatan Dana Desa Di Kecamatan Damau Kabupaten Kepulauan Talaud. Jurnal Riset Akuntansi dan Auditing Goodwill, 8(2).

Septiani, A. (2005). Faktor-Faktor Yang Mempengaruhi Ketepatwaktuan Pelaporan Keuangan Pada Pasar Modal Yang Sedang Berkembang: Perspektif Teori Pengungkapan (Doctoral dissertation, Program Pascasarjana Universitas Diponegoro).

Silalahi, U., \& Mifka, S. A. (2015). Asas-Asas Manajemen.

Subroto, A. (2009). Akuntabilitas Pengelolaan Dana Desa (Studi Kasus Pengelolaan Alokasi Dana Desa Di Desa-Desa Dalam Wilayah Kecamatan Tlogomulyo Kabupaten Temanggung Tahun 2008) (Doctoral dissertation, Universitas Diponegoro).

Sugiyono, P. Dr. (2017). Metode Penelitian Pendidikan: Pendekatan Kuantitatif, Kualitatif, R\&D. Cetakan ke-25. Bandung: CV Alfabeta.

Sulumin, H. H. (2015). Pertanggungjawaban Penggunaan Alokasi Dana Desa Pada Pemerintahan Desa Di Kabupaten Donggala. Katalogis, 3(1).

Tahir, A. (2014). Kebijakan Publik Dan Transparansi Penyelenggaraan Pemerintahan Daerah. Paten, $8(89)$.

Taufik, T. (2009). Pengelolaan Keuangan Desa Dalam Sistem Keuangan Negara Republik Indonesia. Jurnal Ekonomi Universitas Riau, 17(01). 